\title{
Y-Stent-Assisted Coiling of Wide-Neck Bifurcation Intracranial Aneurysms: A Meta-Analysis
}

(D). Cagnazzo, (D) N. Limbucci, DS. Nappini, (D). Renieri, (D) A. Rosi, (D)A. Laiso, DD. Tiziano di Carlo, DP. Perrini, and (D). Mangiafico

\begin{abstract}
BACKGROUND: Y-stent-assisted coiling for wide-neck intracranial aneurysms required further investigation.

PURPOSE: Our aim was to analyze outcomes after Y-stent placement in wide-neck aneurysms.

DATA SOURCES: We performed a systematic search of 3 data bases for studies published from 2000 to 2018.

STUDY SELECTION: According to the Preferred Reporting Items for Systematic Reviews and Meta-Analyses guidelines, we included studies reporting Y-stent-assisted coiling of wide-neck aneurysms.

DATA ANALYSIS: Random-effects meta-analysis was used to pool the following: aneurysm occlusion rate, complications, and factors influencing the studied outcomes.

DATA SYNTHESIS: We included 27 studies and 750 aneurysms treated with Y-stent placement. The immediate complete/near-complete occlusion rate was $82.2 \%\left(352 / 468 ; 95 \% \mathrm{Cl}, 71.4 \%-93 \% ; I^{2}=92 \%\right)$, whereas the long-term complete/near-complete occlusion rate was $95.4 \%$ (564/598; 95\% Cl, 93.7\%-97\%; $\left.\right|^{2}=0 \%$ ) (mean radiologic follow-up of 14 months). The aneurysm recanalization rate was 3\% (20/496; $\left.95 \% \mathrm{Cl}, 1.5 \%-4.5 \% ; \mathrm{I}^{2}=0 \%\right)$, and half of the recanalized aneurysms required retreatment. The treatment-related complication rate was $8.9 \%\left(63 / 614 ; 95 \% \mathrm{Cl}, 5.8 \%-12.1 \% ; \mathrm{I}^{2}=44 \%\right)$. Morbidity and mortality after treatment were $2.4 \%\left(18 / 540 ; 95 \% \mathrm{Cl}, 1.2 \%-3.7 \% ; \mathrm{I}^{2}=0 \%\right)$ and $1.1 \%$ (5/668; 95\% Cl, 0.3\%-1.9\%; $\left.I^{2}=0 \%\right)$, respectively. Crossing Y-stent placement was associated with a slightly lower complication rate compared with the kissing configuration $\left(56 / 572=8.4 \% ; 95 \% \mathrm{Cl}, 5 \%-11 \% ; I^{2}=46 \%\right.$ versus $4 / 30=12.7 \% ; 95 \% \mathrm{Cl}, 3 \%-24 \% ; I^{2}=0 \%$ ). Occlusion rates were quite comparable among Enterprise, Neuroform, and LVIS stents, whereas the Enterprise stent was associated with lower rates of complications $\left(8 / 89=6.5 \% ; 95 \% \mathrm{Cl}, 1.6 \%-11 \% ; \mathrm{I}^{2}=0 \%\right)$ compared with the others $\left(20 / 131=14 \% ; 95 \% \mathrm{Cl}, 5 \%-26 \% ; \mathrm{I}^{2}=69 \%\right.$ and $\left.9 / 64=11 \% ; 95 \% \mathrm{Cl}, 3 \%-20 \% ; I^{2}=18 \%\right)$.
\end{abstract}

LIMITATIONS: This was a small, retrospective series.

CONCLUSIONS: Y-stent-assisted coiling yields high rates of long-term angiographic occlusion, with a relatively low rate of treatmentrelated complications. Y-stent placement with a crossing configuration appears to be associated with better outcomes. Although Y-configuration can be obtained using many types of stents with comparable occlusion rates, the Enterprise stent is associated with lower complication rates.

ABBREVIATIONS: IQR = interquartile range; PRISMA = Preferred Reporting Items for Systematic Reviews and Meta-Analyses; SAC = stent-assisted coiling; Y-SAC $=$ Y-stent-assisted coiling

W ith the improvement of angiographic imaging, operator experience, and widespread use of more complex techniques, an increased number of intracranial aneurysms can be

Received August 28, 2018; accepted after revision October 15.

From the Interventional Neuroradiology Unit (F.C., N.L., S.N., L.R., A.R., A.L., S.M.) Careggi University Hospital, Florence, Italy; and Department of Neurosurgery (D.T.d.C., P.P.), Cisanello Hospital, University of Pisa, Pisa, Italy.

Please address correspondence to Federico Cagnazzo, MD, Interventional Neuroradiology Unit, AOU Careggi, CTO, Largo P Palagi 1, Florence 50134, Italy; e-mail: f.cagnazzo86@gmail.com effectively treated with endovascular techniques. However, aneurysms with wide necks, unfavorable anatomic configurations, and partial incorporation of bifurcation branches are still challenging lesions for endovascular treatment, and each technique presents specific limitations. Balloon-assisted coiling may not be suitable in case of very wide-neck aneurysms with complex anatomy. ${ }^{1}$

Indicates article with supplemental on-line tables.

5 Indicates article with supplemental on-line photos.

http://dx.doi.org/10.3174/ajnr.A5900 
Flow diversion appears to be a straightforward treatment, but the fate of the covered side branches in case of bifurcation aneurysms may be a concern. ${ }^{2,3}$ Intrasaccular flow disruption seems to be an effective tool for wide-neck aneurysms, and treatment-related outcomes continue to improve due to better case selection, technology, and technical improvement, despite long-term angiographic occlusion rates that are still lower than those of stentassisted coiling (SAC). ${ }^{4}$ Finally, PulseRider (Cerenovus, New Brunswick, New Jersey) and pCONus aneurysm implant (phenox, Bochum, Germany) devices appear to be promising new strategies to treat wide-neck lesions, though long-term studies are needed to confirm the efficacy of these devices. ${ }^{5,6}$

Y-stent-assisted coiling (Y-SAC), first proposed by Chow et $\mathrm{al},{ }^{7}$ in 2004, is performed by placing 2 stents from the parent artery into each of the bifurcation vessels, creating a new bifurcation point that provides a mechanical scaffold, preventing coil protrusion. ${ }^{8}$ To date, the feasibility of this procedure has been confirmed by small retrospective series, but there has not been sufficient evaluation of the safety and efficacy of this technique. Improved understanding of treatment-related outcomes after YSAC can help practitioners in the selection of lesions that can be effectively treated with this strategy. Our meta-analysis examined occlusion rates and procedure-related complications, focusing on the influence of aneurysm and patient features and treatment characteristics on the studied outcomes.

\section{MATERIALS AND METHODS Literature Search}

A comprehensive literature search of PubMed, Ovid MEDLINE, and Ovid EMBASE was conducted for studies published from January 2000 to August 2018. The Preferred Reporting Items for Systematic Reviews and Meta-Analyses (PRISMA) ${ }^{9}$ guidelines were followed. The key words and detailed search strategy are reported in On-line Table 1, and the studies included in our review are reported in On-line Table 2. The inclusion criteria were the following: studies reporting series with $>5$ patients with bifurcation intracranial aneurysms treated with Y-SAC. Exclusion criteria were the following: 1) case reports, 2) review articles, 3) studies published in languages other than English, 4) in vitro/ animal studies, and 5) series reporting aneurysms treated with $\mathrm{X}$-stent placement. In cases of overlapping patient populations, only the series with the largest number of patients or the most detailed data were included. Two independent readers screened articles in their entirety to determine eligibility for inclusion. A third author solved discrepancies.

\section{Data Collection}

We extracted the following data: 1) technical success rate, 2) occlusion rate, 3) treatment-related complications, and 4) clinical outcome. Occlusion and complication rates were analyzed on the basis of the influence of the following: 1) aneurysm location; 2) ruptured-versus-unruptured aneurysms; 3 ) aneurysm size: small saccular $(<5 \mathrm{~mm})$ and medium-sized aneurysms (between 5.0 and $9.9 \mathrm{~mm}$ ) versus large (between 10 and $20 \mathrm{~mm}$ ) and very large and giant aneurysms $(>20 \mathrm{~mm}) ; 4$ ) patient age (younger than 60 years versus older than 60 years); 5) crossing-versus-kissing Yconfiguration; 6) type of stent used; and 7) hybrid-versus-nonhy- brid configuration. In the hybrid configuration, an open-cell stent (Neuroform; Stryker Neurovascular, Kalamazoo, Michigan) was used with a closed-cell stent (usually Enterprise self-expanding stent; Codman \& Shurtleff, Raynham, Massachusetts).

Complete/near-complete aneurysm occlusion was defined on the basis of the following: Raymond-Roy classification ${ }^{10}$ (class $1-2$ ), or when "complete occlusion" and "neck remnant" were used in the study. Treatment-related complications were divided into the following: 1) periprocedural/early events (within 30 days) and delayed events (after 30 days); 2) transient (asymptomatic events or complete neurologic recovery) and permanent complications (symptomatic events with permanent deficits); and 3) ischemic and hemorrhagic complications. Finally, good outcome was defined as a modified Rankin Scale score of $0-2$ or a Glasgow Outcome Score of 4-5, or it was assumed if the study used terms "no morbidity," "good recovery," or "no symptoms."

\section{Outcomes}

The primary objectives of this study were to define the safety (treatment-related complications, mortality rate, and neurologic outcomes) and efficacy (technical success rate, immediate and long-term occlusion) of Y-SAC. The secondary objectives were to define the influence of aneurysm, patient, and treatment characteristics on the analyzed outcomes.

\section{Quality Scoring}

The Newcastle-Ottawa Scale ${ }^{11}$ was used for the quality assessment of the included studies (details in On-line Table 3). The quality assessment was performed by 2 authors independently, and a third author solved discrepancies.

\section{Statistical Analysis}

We estimated, from each cohort, the cumulative prevalence (percentage) and 95\% confidence interval for each outcome. Heterogeneity of the data was assessed by the Higgins index $\left(\mathrm{I}^{2}\right)$, and subsequently, the DerSimonian and Laird random-effects model was applied. The graphic representation was shown by a forest plot. To evaluate the heterogeneity and bias, the meta-regression and funnel plot followed by the Egger linear regression test were analyzed, respectively. To compare the percentages and to calculate the $P$ values, a $Z$-test for 2 proportions was used. Differences were considered significant at $P<.05$. Meta-analysis was performed with ProMeta-2 (Internovi; Cesena, Italy) and OpenMeta[Analyst] (http://www.cebm.brown.edu/openmeta/).

\section{RESULTS}

\section{Literature Review}

Studies included in our meta-analysis are summarized in On-line Table 2. The search flow diagram is shown in On-line Fig 1.

Twenty-seven studies and 750 aneurysms treated with Y-SAC were included in our review.

\section{Quality of Studies}

Studies included in our review were retrospective series: Two studies were retrospective multicentric series, whereas 25 articles were single-center retrospective series. Details of the rating of the included studies are reported in On-line Table 3. 


\begin{tabular}{|c|c|c|c|}
\hline Variables & $\begin{array}{c}\text { Results of Systematic Review } \\
\text { and Meta-Analysis }\end{array}$ & $\begin{array}{c}\text { No. of } \\
\text { Articles }\end{array}$ & Statistic $(95 \% \mathrm{Cl})\left(\mathrm{I}^{2}\right)$ \\
\hline \multicolumn{4}{|l|}{ Angiographic outcomes } \\
\hline Rate of successful stent deployment & $550 / 569=97 \%$ & 20 & $(96-99)\left(I^{2}=0 \%\right)$ \\
\hline Immediate aneurysm occlusion rate (RR 1-2) & $352 / 468=82.2 \%$ & 15 & $(71.4-93)\left(1^{2}=92 \%\right)$ \\
\hline Long-term aneurysm occlusion rate (RR 1-2) & $564 / 598=95.4 \%$ & 24 & $(93.7-97)\left(1^{2}=0 \%\right)$ \\
\hline Aneurysm recanalization & $20 / 496=3 \%$ & 19 & $(1.5-4.5)\left(1^{2}=0 \%\right)$ \\
\hline Recanalization among anterior circulation & $2 / 89=2 \%$ & 9 & $(0.9-9)\left(1^{2}=0 \%\right)$ \\
\hline Recanalization among posterior circulation & $11 / 130=4 \%$ & 12 & $(2-9)\left(1^{2}=0 \%\right)$ \\
\hline Mean size of recanalized vs nonrecanalized aneurysms ( $\mathrm{mm})$ & $11 \pm 2.4$ vs $7 \pm 1.18$ & 7 & \\
\hline Rate of retreatment of recanalized aneurysms & $10 / 20=50 \%$ & 19 & $(29-70)$ \\
\hline \multicolumn{4}{|l|}{ Treatment-related complications and clinical outcomes } \\
\hline Overall treatment-related complications & $63 / 614=8.9 \%$ & 23 & $(5.8-12.1)\left(I^{2}=44 \%\right)$ \\
\hline Periprocedural/early complications (within 30 days) & $46 / 574=6.7 \%$ & 21 & $(4-9)\left(1^{2}=35 \%\right)$ \\
\hline Delayed complications (after 30 days) & $9 / 574=2.1 \%$ & 21 & $(1-3)\left(1^{2}=0 \%\right)$ \\
\hline Transient complications & $33 / 540=6.5 \%$ & 20 & $(2.2-6)\left(1^{2}=21 \%\right)$ \\
\hline Symptomatic complications without permanent deficits & $22 / 540=3 \%$ & 20 & $(1.3-4)\left(1^{2}=35 \%\right)$ \\
\hline Permanent complications & $18 / 540=2.4 \%$ & 20 & $(1.2-3.7)\left(I^{2}=0 \%\right)$ \\
\hline Treatment-related mortality & $5 / 668=1.1 \%$ & 23 & $(0.3-1.9)\left(I^{2}=0 \%\right)$ \\
\hline Overall rate of good neurologic outcome & $291 / 317=94.5 \%$ & 15 & $(92-97)\left(I^{2}=7 \%\right)$ \\
\hline \multicolumn{4}{|l|}{ Type of complications } \\
\hline Thromboembolic complications & $44 / 594=6.5 \%$ & 22 & $(3-7.6)\left(1^{2}=29 \%\right)$ \\
\hline Hemorrhagic complications & $11 / 594=2 \%$ & 22 & $(0.7-3)\left(1^{2}=0 \%\right)$ \\
\hline Acute in-stent thrombosis & $20 / 577=2.1 \%$ & 22 & $(1.6-6)\left(1^{2}=0 \%\right)$ \\
\hline Aneurysm rupture after treatment & $0 / 650=0 \%$ & 22 & \\
\hline Chronic in-stent stenosis & $10 / 295=2.3 \%$ & 11 & $(0.6-4)\left(1^{2}=0 \%\right)$ \\
\hline
\end{tabular}

Note:-RR indicates Raymond-Roy grade.

\section{Patient Population and Aneurysm Characteristics}

Overall, 744 patients and 750 aneurysms were treated with Y-SAC (On-line Table 4). The mean age of patients was 56.6 years (range, $22-80$ years), and the proportion of male patients was 36\% (95\% CI, 32\%-40\%). Aneurysms included in our study were wide-neck saccular bifurcation aneurysms. Overall, 61\% (366/601; 95\% CI, $56 \%-64 \%$ ) were anterior circulation aneurysms, whereas $39 \%$ (235/601; 95\% CI, 35\%-43\%) were posterior circulation lesions. Most of the aneurysms were located at the basilar tip $(235 / 601=$ $39 \%$; 95\% CI, 35\%-43\%), middle cerebral artery bifurcation $(206 / 601=34.4 \%$; 95\% CI, 30\%-38\%), and anterior communicating artery $(120 / 601=20 \%$; 95\% CI, 16\%-23\%). Mean aneurysm size was $9.6 \mathrm{~mm}$ (median, $9.9 \mathrm{~mm}$; interquartile range [IQR] $=8-10.5 \mathrm{~mm}$; range, $3-25 \mathrm{~mm}$ ). The proportion of acutely ruptured aneurysms treated with Y-stent placement was 11\% (66/ 592; 95\% CI, 8.5\%-14\%).

\section{Treatment Characteristics}

The most common stent used was the Enterprise $(476 / 1060=$ $45 \%$; $95 \%$ CI, 42\%-47\%), followed by the Neuroform (332/ $1060=31.3 \%$; 95\% CI, 28\%-40\%), LVIS stents (MicroVention, Tustin, California) $(132 / 1060=12.5 \%$; 95\% CI, 10\%-14\%), Solitaire (Covidien, Irvine, California) $(66 / 1060=6.2 \%$; $95 \% \mathrm{CI}$, 4.9\%-7.8\%), and Acclino flex Stent (Acandis, Pforzheim, Germany) $(54 / 1060=5 \% ; 95 \%$ CI, 3.9\%-6.6\%). Nonhybrid (closed/closed-cell and open/open-cell stents) and hybrid (closed/open-cell stents) techniques were used in $87.5 \%$ (512/ 585; 95\% CI, 84\%-98\%) and 12.5\% (73/585; 95\% CI, 10\%-15\%) of aneurysms, respectively. Y-stent placement with a crossing configuration was the most common technique $(688 / 750=92 \%$; 95\% CI, 89\%-93\%), followed by kissing stent placement (60/ $750=8 \%$; 95\% CI, 6\%-10\%). The mean radiologic (digital subtraction angiography) follow-up was 14 months (range, 6-24 months; median, 12 months; IQR $=10-18$ months), and the mean clinical follow-up was 17 months (range, 3-30 months; median, 16.5 months; IQR $=7.8-21$ months).

\section{Angiographic Outcomes}

The technical success rate was 97\% (550/569; 95\% CI, 96\%-99\%; $\mathrm{I}^{2}=0 \%$ ) (Table). Immediate angiographic occlusion after treatment was obtained in $82.2 \%\left(352 / 468\right.$; 95\% CI, 71.4\%-93\%; $\mathrm{I}^{2}=$ $92 \%$ ) of aneurysms. The rate of long-term complete/near-complete occlusion was $95.4 \%$ (564/598; 95\% CI, 93.7\%-97\%; $\mathrm{I}^{2}=$ $0 \%)$. Meta-regression showed a nonsignificant variation of the effect size $(P=.056)$, and the funnel plot, followed by the Egger linear regression test, excluded publication bias $(P=.358)$ (Online Fig 2).

Aneurysm recanalization occurred in 3\% (20/496; 95\% CI, $\left.1.5 \%-4.5 \% ; \mathrm{I}^{2}=0 \%\right)$ of cases, and half of the recanalized aneurysms required retreatment. The mean size of recanalized and nonrecanalized aneurysms was $11 \pm 2.4$ versus $7 \pm 1.18$ $\mathrm{mm}(P=.0001)$. The aneurysm recanalization rate was $2 \%$ $\left(2 / 89 ; 95 \%\right.$ CI, $\left.0.9 \%-9 \% ; \mathrm{I}^{2}=0 \%\right)$ and $4 \%(11 / 130 ; 95 \% \mathrm{CI}$, $\left.2 \%-9 \% ; \mathrm{I}^{2}=0 \%\right)$ among the anterior and posterior circulation, respectively $(P=.4)$.

\section{Treatment-Related Complications}

The overall complication rate was $8.9 \%$ (63/614; 95\% CI, 5.8\%$12.1 \%$; $\mathrm{I}^{2}=44 \%$ ) (Table). Meta-regression showed a nonsignificant variation of the effect size $(P=.443)$, and the funnel plot, followed by the Egger linear regression test, excluded publication bias $(P=.574)$ (On-line Fig 3$)$. Periprocedural/early complications were $6.7 \%\left(46 / 574 ; 95 \% \mathrm{CI}, 4 \%-9 \% ; \mathrm{I}^{2}=35 \%\right)$. Delayed complications were $2.1 \%\left(9 / 574 ; 95 \% \mathrm{CI}, 1 \%-3 \% ; \mathrm{I}^{2}=0 \%\right)(3$ cases of in-stent occlusion, 5 ischemic events, 1 thromboembolism after discontinuation of the antiplatelet therapy). Transient 
(with and without related symptoms) and permanent complications were $6.5 \%\left(33 / 540 ; 95 \% \mathrm{CI}, 2.2 \%-6 \%\right.$; $\left.\mathrm{I}^{2}=21 \%\right)$ and $2.4 \%$ (18/540; 95\% CI, 1.2\%-3.7\%; $\left.\mathrm{I}^{2}=0 \%\right)$, respectively. The rate of symptomatic complications without permanent deficits (transient events with related symptoms) was 3\% (22/540; 95\% CI, $1.3 \%-4 \% ; \mathrm{I}^{2}=35 \%$ ).

Overall, ischemic/thromboembolic, and hemorrhagic events were $6.5 \%\left(44 / 594 ; 95 \% \mathrm{CI}, 3.7 \%-6 \% ; \mathrm{I}^{2}=29 \%\right)$ and $2 \%(11 /$ 594; 95\% CI, 0.7\%-3\%; $\mathrm{I}^{2}=0 \%$ ), respectively. The rate of acute in-stent thrombosis was $2.1 \%\left(20 / 577 ; 95 \% \mathrm{CI}, 1.6 \%-6 \%\right.$; $\mathrm{I}^{2}=$ $0 \%)$ and chronic in-stent stenosis $(>50 \%)$ was $2.3 \%(10 / 295$; $95 \%$ CI, $0.6 \%-4 \%$; $\mathrm{I}^{2}=0 \%$ ). There were no cases of aneurysm rupture after treatment during follow-up.

Treatment-related mortality was $1.1 \%$ (5/668; 95\% CI, 0.3\%$\left.1.9 \% ; \mathrm{I}^{2}=0 \%\right)$, and the rate of good neurologic outcome was 94.5\% (291/317; 95\% CI, 92\%-97\%; $\left.\mathrm{I}^{2}=7 \%\right)$.

\section{Factors Related to Aneurysm Occlusion}

Overall, the occlusion rate was comparable among ruptured-versus-unruptured aneurysms $(P=.2)$, anterior-versus-posterior circulation $(P=.27)$, patients younger-versus-older than 60 years $(P=.5)$, crossing-versus-kissing techniques $(P=.2)$, and hybrid-versus-nonhybrid techniques $(P=.2)$. Long-term occlusion was significantly higher among small and mediumsized versus large or very large/giant aneurysms $(98 / 107=$ 92\%; 95\% CI, 86\%-96\%; $\mathrm{I}^{2}=0 \%$ versus $33 / 43=79 \%$; $95 \%$ CI, 67\%-91\%; $\left.\mathrm{I}^{2}=25 \%\right)(P=.02)$ and among aneurysms treated with Y-stent placement used as the first treatment versus retreatment $\left(119 / 128=94 \%\right.$; 95\% CI, 89\%-98\%; $\mathrm{I}^{2}=0 \%$ versus $40 / 48=82 \%$; 95\% CI, 71\%-92\%; $\left.\mathrm{I}^{2}=0 \%\right)(P=.01)$ (On-line Table 5). MCA aneurysms had higher occlusion rates $\left(52 / 54=94.9 \%\right.$; 95\% CI, 89\%-97\%; $\left.\mathrm{I}^{2}=0 \%\right)$ compared with basilar tip aneurysms $(126 / 145=88.8 \%$; 95\% CI, 83\%-93\%; $\left.\mathrm{I}^{2}=0 \%\right)$ and anterior cerebral artery location $(42 / 46=87 \%$; 95\% CI, 78\%-96\%; $\left.\mathrm{I}^{2}=0 \%\right)(P>.05)$.

\section{Factors Related to Complications after Treatment}

The complication rate was higher for ruptured $(11 / 52=18 \%$; 95\% CI, 7\%-28\%; $\left.\mathrm{I}^{2}=21 \%\right)$ compared with unruptured aneurysms $\left(29 / 236=8 \% ; 95 \% \mathrm{CI}, 4.5 \%-13 \% ; \mathrm{I}^{2}=36 \%\right)(P=.02)$. There was no statistically significant difference in complication rates in relation to aneurysm location, patient age, aneurysm size, and technical factors (On-line Table 5).

\section{Relationship between Type of Stent Used and Treatment- Related Outcomes}

Treatment with the Enterprise stent was associated with 96\% (98/ $101 ; 95 \%$ CI, 93\%-98\%; $\mathrm{I}^{2}=0 \%$ ) long-term occlusion and $6.5 \%$ (8/99; 95\% CI, 1.6\%-11\%; $\left.\mathrm{I}^{2}=0 \%\right)$ complications. Aneurysm occlusion during follow-up and treatment-related complications after Neuroform stent placement were 94\% (119/130; 95\% CI, $\left.90 \%-98 \% ; \mathrm{I}^{2}=14 \%\right)$ and $14 \%\left(20 / 131 ; 95 \% \mathrm{CI}, 5 \%-26 \% ; \mathrm{I}^{2}=\right.$ $69 \%)$, respectively. Finally, treatment with the LVIS and LVIS Jr stents yielded $92 \%\left(52 / 56 ; 95 \% \mathrm{CI}, 85 \%-99 \% ; \mathrm{I}^{2}=0 \%\right)$ and $11 \%$ (9/64; 95\% CI, 3\%-20\%; $\mathrm{I}^{2}=18 \%$ ) long-term occlusion and complications rates, respectively.

\section{Study Heterogeneity}

Substantial heterogeneity was reported in the following outcomes: technical success rate, overall rate of treatment-related complications, occlusion rate among patients younger than 60 years, and complications after treatment with the Neuroform stent.

\section{DISCUSSION}

\section{Angiographic Outcomes}

Our meta-analysis stressed several important findings related to the treatment of complex wide-neck bifurcation aneurysms requiring Y-SAC. Y-stent placement always needs the catheterization of both bifurcation branches, which sometimes may be complex in case of steep angles. Moreover, Y-stent placement with the crossing technique, which is more common than the kissing one, needs the passage of a second stent through the interstices of the first deployed device, necessitating microcatheterization through a recently placed stent, with the risk of damage/dislodgement of the first stent. ${ }^{12}$ However, our study showed a high technical success rate $(97 \%)$, demonstrating that $\mathrm{Y}-\mathrm{SAC}$ is a feasible technique in experienced centers.

While $82.2 \%$ of aneurysms were occluded immediately after treatment, nearly $95 \%$ of the lesions had complete/near-complete occlusion during the 14 months of radiologic follow-up. The immediate occlusion rate reported in the literature is quite variable, ranging from $50 \%$ to $100 \%,{ }^{8,12,13}$ whereas long-term occlusion rates appear homogeneous. Assessing the heterogeneity of the data, we found a low rate of $\mathrm{I}^{2}$ for the long-term occlusion rate and a very high rate of $\mathrm{I}^{2}$ for the immediate occlusion rate. It is likely that the flow-diversion effect of the $2 \mathrm{Y}$-configured stents influenced the aneurysm thrombosis, and lesions with a lower occlusion rate immediately after treatment were completely occluded at the last angiographic follow-up. Cekirge et $\mathrm{al}^{14}$ reported a series of 8 bifurcation aneurysms treated by placing 2 stents in a Y-configuration with no accompanying endosaccular packing. Given the flow-diversion effect of the stents, 6 aneurysms had complete occlusion and 2 lesions showed residual filling during about 12 months of follow-up. Because we analyzed a period of about 13 years, it is likely that the evolution of the devices (low-profile stents compatible with 0.0165 -inch inner microcatheters) and the improvement of the operator experience would have influenced the outcomes. Accordingly, although it was not statistically significant, we found a trend $(P=.056)$ toward a higher occlusion rate over the analyzed period (On-line Fig 2). Given the high rate of long-term occlusion, only $3 \%$ of aneurysms were recanalized during follow-up, without statistically significant differences between the anterior and posterior circulation. These results appear comparable with those reported in a series of wide-neck aneurysms treated with PulseRider ${ }^{6}$ and pCONus $^{5}$ devices, showing rates of Raymond-Roy 1-2 occlusion close to $95 \%$, with $5 \%$ recanalization. Among large meta-analyses of aneurysms treated with the Woven EndoBridge (WEB; Sequent Medical, Aliso Viejo, California) devices, long-term complete/near-complete occlusion ranged from $80 \%$ to $85 \%$, with a nearly $7 \%$ retreatment rate. ${ }^{4,15}$

Long-term occlusion of large and giant aneurysms is notoriously challenging after selective endovascular treatment. ${ }^{17}$ Our study found that an occlusion rate after Y-stent placement was 
lower among large/giant aneurysms (79\% versus 92\%, $P=.02$ ), and the mean size of recanalized aneurysms was higher $(11 \mathrm{~mm})$ compared with nonrecanalized lesions $(7 \mathrm{~mm})(P=.0001)$.

Y-SAC can be used as a first treatment or in the retreatment of recanalized aneurysms. Jeon et al, ${ }^{17}$ in a series of 25 patients with basilar tip aneurysms treated using Y-stent placement with closed-cell stents, reported $70 \%$ complete occlusion among recanalized aneurysms, and 100\% occlusion among those directly treated with Y-stent placement. Our meta-analysis confirmed higher occlusion rates after $Y$-stent placement used as a first treatment (94\% versus $82 \%, P=.01$ ), probably because recanalized aneurysms are generally those with more complex anatomy.

\section{Treatment-Related Complications}

One of the main concerns of Y-SAC is the risk of ischemic complications related to the increased metal density of the overlapped double stents that promotes platelet aggregation. In our meta-analysis, Y-stent placement was associated with an $8.9 \%$ complication rate, with a moderate statistical heterogeneity over the included studies. Most complications occurred in the periprocedural/early period after treatment $(6.7 \%)$, with a low rate of treatment-related morbidity $(2.4 \%)$ and mortality (1\%). Delayed complications were $2.1 \%$, and most were associated with asymptomatic in-stent occlusion. ${ }^{18-20}$ Overall, thromboembolism was the most common complication $(6.5 \%)$, whereas acute in-stent occlusion was reported among $2 \%$ of cases. Hemorrhagic events were uncommon and were generally related to technical complications during the crossing maneuver through the interstices of the first stent (aneurysm or vessel perforation). ${ }^{8}$ No lesions ruptured (delayed hemorrhage) after treatment during follow-up, demonstrating that the aneurysms were successfully secured.

In a meta-analysis of nearly 2500 wide-neck aneurysms treated endovascularly, the permanent complication rates were $2 \%$ and $3 \%$ for coiling and SAC, respectively. ${ }^{21}$ Flow-diverter stents have become a suitable tool for complex wide-neck aneurysms. However, an important concern is the patency of the covered side branches when the stent is deployed at the bifurcation points. Recently, a meta-analysis of approximately 250 MCA aneurysms treated with flow-diverter stents showed an overall complication rate of $20 \%$, with $10 \%$ treatment-related morbidity. In addition, nearly $10 \%$ of jailed arteries were occluded during follow-up. ${ }^{3}$ Intrasaccular flow disruption with WEB devices appeared to be relatively safe, with $8 \%$ thromboembolic complications, which were lower (6\%) among studies published after 2013, due to the improvement in the operators' experience. ${ }^{4}$ Similarly, although current evidence is still limited, PulseRider can be a suitable option for wide-neck aneurysms: A recent review showed $8 \%$ intraprocedural complications, which is quite comparable with the treatment-related outcomes of Y-SAC. ${ }^{22}$

According to a large series and meta-analysis of very large and giant aneurysms treated endovascularly, ${ }^{16}$ we found higher complication rates among large-giant lesions (17\%) compared with small- or medium-sized aneurysms (9\%). In addition, patients who underwent retreatment with Y-stent placement of a recanalized aneurysm experienced a higher complication rate (14\% versus $7.6 \%$ ). This is likely a reflection of a more complex anatomic configuration and larger neck of the recanalized aneurysms; in this situation, retreatment can be technically challenging.

In our study, Y-stent placement for MCA aneurysms showed better results, especially if compared with anterior cerebral artery lesions, which were associated with complication rates close to $20 \%$. Anterior communicating artery aneurysms usually have a complex anatomy, while pericallosal lesions are characterized by distal access and small arterial caliber, increasing the risk of complications. $^{20,23,24}$

\section{Crossing-versus-Kissing Technique}

In general, the crossing-Y-stent placement is the most commonly used technique; the second stent is deployed through the cells of the first stent. In our study, $92 \%$ of patients were treated with the crossing technique, and $8 \%$, with the kissing approach. The crossing technique necessitates passing a wire and stent through a recently placed stent, thus risking damage/dislodgement of the first device. ${ }^{19}$ The kissing technique avoids this problem due to the use of 2 stents placed side by side in the parent artery with the distal segment of each stent going into 1 bifurcation vessel. ${ }^{19,25}$ However, no studies compared these 2 techniques. In our review (Online Table 5) complete/near complete occlusion rate (RaymonRoi grade 1 and 2) was quite comparable, and it was achieved in $95 \%$ and $90 \%$ of aneurysms treated with crossing and kissing Y-stent placement, respectively. However, the complication rate appeared to be slightly higher after kissing stent placement $(12.7 \%$ versus $8.4 \%$ ), though the difference was not statistically significant, probably due to the small number of patients in the kissing group.

Brassel et $\mathrm{al}^{27}$ reported $14 \%$ ischemic complications in a series of 7 complex aneurysms treated with the kissing-Y-technique with the closed-cell Acclino flex Stent. Complete occlusion was reported in all 7 aneurysms. Jankowitz et al ${ }^{19}$ reported an $80 \%$ complete occlusion after Y-stent placement with the kissing technique in 11 wide-neck aneurysms. One patient had a procedural aneurysm rupture, and 1 patient experienced delayed in-stent thrombosis. Accordingly, the efficacy and safety of kissing Y-stent placement probably needs larger series to be proved.

\section{Closed-Cell and Open-Cell Stents}

Y-stent placement embolization can be achieved by using various combinations of different types of stent: closed/closed-cell (such as the Enterprise), open/open-cell (Neuroform), or a hybrid combination between closed and open-cell stents. Limbucci et $\mathrm{al}^{8}$ reported a high rate of long-term occlusion (97\%) and a relatively low rate of complications (4\%) after Y-stent placement performed with 2 Enterprise stents in a crossing fashion. Laser-cut closed-cell devices had good navigability, and they are usually easily deployed because they can be partially recapturable. In addition, the linear profile of 2 closed-cell stents may allow a better scaffold and protection of the parent artery during coiling. ${ }^{8}$ However, an important concern using 2 closed-cell stents is that the first device may limit the expansion of the second one, resulting in in-stent stenosis. In our study, Y-stent placement with 2 Enterprise devices was associated with high rates of occlusion (96\%) and a low rate of complications (6.5\%) (On-line Table 6). 
Although infrequently specified in the included studies, most Neuroform stents were the older generation devices. Castaño et $\mathrm{al}^{26}$ described a series of patients treated with different generations of Neuroform stents, including the Neuroform Atlas Stent System in past years, reporting $95 \%$ occlusion and a very low rate of treatment-related complications $(2.5 \%)$ after Y-stent placement. The authors reported that in their experience, open-cell stents had good conformability to tortuous anatomies, minor rectification of the vessels, high vessel wall apposition, and easier microcatheterization through the mesh of the first stent. However, if one investigated the literature, complications after Y-stent placement with the Neuroform stent appear quite variable, ranging from $2 \%$ to $25 \%$. Spiotta et $\mathrm{al}^{27}$ reported 5 periprocedural events during Y-stent placement in 19 patients with the Neuroform stent. Our meta-analysis showed 14\% complications associated with Y-stent placement using the Neuroform stent. However, most were transient events without clinical sequalae.

Recently, braided stents have been used to perform Y-SAC. Compared with other stents that are laser-cut from nitinol hypotubes, LVIS stents are braided from a single nitinol wire with a closed-cell design. Theoretically, they have a smaller cell size and higher metal coverage and flow-diversion effect than other conventional self-expandable devices. ${ }^{24,28}$ We found $92 \%$ occlusion and $11 \%$ complications using LVIS stents.

Finally, 4 studies ${ }^{12,19,29,30}$ reported results after Y-stent placement performed with a combination (hybrid design) of closed/ open-cell stents (Enterprise/Neuroform). Usually the Neuroform stent was chosen as a first stent to stabilize the structure; a second Enterprise stent can be better deployed through the interstices of the Neuroform stent that are wider than those in closed-cell devices. In our study, the overall occlusion rate was $90 \%$, with $7.5 \%$ treatment-related complications.

\section{Strengths and Limitations}

Our study has limitations. The series are retrospective studies or small single-institution experiences. Because of the small number of cases in some subgroup analyses, the comparisons among them may not provide power to show a statistically significant difference among the studied outcomes. However, publication bias was excluded, and our review is the largest to date.

\section{CONCLUSIONS}

Although Y-SAC is usually performed in complex aneurysms, high rates of long-term angiographic occlusion are achieved with a relatively low rate of treatment-related complications. Y-stent placement with a crossing configuration appears associated with better outcomes. Even though a Y-configuration can be obtained with many types of stents with comparable occlusion rates, the Enterprise stent appears to be associated with lower rates of complications.

Disclosures: Federico Cagnazzo_UNRELATED: Employment: University of Florence. Antonio Laiso-UNRELATED: Fees for Participation in Review Activities such as Data Monitoring Boards, Statistical Analysis, Endpoint Committees. Paolo PerriniUNRELATED: Employment: University of Pisa.

\section{REFERENCES}

1. Pierot L, Wakhloo AK. Endovascular treatment of intracranial aneurysms: current status. Stroke 2013;44:2046-54 CrossRef Medline

2. Cagnazzo F, Lefevre PH, Mantilla D, et al. Patency of the supraclinoid internal carotid artery branches after flow-diversion treatment: a meta-analysis. J Neuroradiol 2018 Aug 9. [Epub ahead of print] CrossRef Medline

3. Cagnazzo F, Mantilla D, Lefevre PH, et al. Treatment of middle cerebral artery aneurysms with flow-diverter stents: a systematic review and meta-analysis. AJNR Am J Neuroradiol 2017;38:2289-94 CrossRef Medline

4. Lv X, Zhang Y, Jiang W. Systematic review of Woven EndoBridge for wide-necked bifurcation aneurysms: complications, adequate occlusion rate, morbidity, and mortality. World Neurosurg 2018;110: 20-25 CrossRef Medline

5. Gory B, Aguilar-Pérez M, Pomero E, et al. One-year angiographic results after pCONus stent-assisted coiling of 40 wide-neck middle cerebral artery aneurysms. Neurosurgery 2017;80:925-33 CrossRef Medline

6. Gory B, Spiotta AM, Di Paola F, et al. PulseRider for treatment of wide-neck bifurcation intracranial aneurysms: 6-month results. World Neurosurg 2017;99:605-09 CrossRef Medline

7. Chow MM, Woo HH, Masaryk TJ, et al. A novel endovascular treatment of a wide-necked basilar apex aneurysm by using a Y-configuration, double-stent technique. AJNR Am J Neuroradiol 2004;25: 509-12 Medline

8. Limbucci N, Renieri L, Nappini S, et al. Y-stent assisted coiling of bifurcation aneurysms with Enterprise stent: long-term follow-up. J Neurointerv Surg 2016;8:158-62 CrossRef Medline

9. Moher D, Liberati A, Tetzlaff J, et al. Preferred reporting items for systematic reviews and meta-analyses: the PRISMA statement. Int J Surg 2010;8:336-41 CrossRef Medline

10. Roy D, Milot G, Raymond J. Endovascular treatment of unruptured aneurysms. Stroke 2001;32:1998-2004 CrossRef Medline

11. Wells G, Shea B, O'Connell D. The Newcastle-Ottawa Scale (NOS) for Assessing the Quality of Nonradomized Studies in Meta-Analyses. Ottawa: Ottawal Hospital Research Institute. 2011 http://www. evidencebasedpublichealth.de/download/Newcastle_Ottowa_Scale_ Pope_Bruce.pdf. Accessed August 20, 2018

12. Fargen KM, Mocco J, Neal D, et al. A multicenter study of stentassisted coiling of cerebral aneurysms with a Y configuration. $\mathrm{Neu}$ rosurgery 2013;73:466-72 CrossRef Medline

13. Yavuz K, Geyik S, Cekirge S, et al. Double stent-assisted coil embolization treatment for bifurcation aneurysms: immediate treatment results and long-term angiographic outcome. AJNR Am J Neuroradiol 2013;34:1778-84 CrossRef Medline

14. Cekirge HS, Yavuz K, Geyik S, et al. A novel "Y" stent flow diversion technique for the endovascular treatment of bifurcation aneurysms without endosaccular coiling. AJNR Am J Neuroradiol 2011;32: 1262-68 CrossRef Medline

15. Asnafi S, Rouchaud A, Pierot L, et al. Efficacy and safety of the Woven EndoBridge (WEB) device for the treatment of intracranial aneurysms: a systematic review and meta-analysis. AJNR Am J Neuroradiol 2016;37:2287-92 CrossRef Medline

16. Cagnazzo F, Mantilla D, Rouchaud A, et al. Endovascular treatment of very large and giant intracranial aneurysms: comparison between reconstructive and deconstructive techniques - a meta-analysis. AJNR Am J Neuroradiol 2018;39:852-58 CrossRef Medline

17. Jeon P, Kim BM, Kim DJ, et al. Y-configuration double-stent-assisted coiling using two closed-cell stents for wide-neck basilar tip aneurysms. Acta Neurochir (Wien) 2014;156:1677-86 CrossRef Medline

18. Bartolini B, Blanc R, Pistocchi S, et al. "Y" and " $X$ " stent-assisted coiling of complex and wide-neck intracranial bifurcation aneurysms. AJNR Am J Neuroradiol 2014;35:2153-58 CrossRef Medline

19. Jankowitz BT, Thomas A, Jovin T, et al. Y stenting using kissing 
stents for the treatment of bifurcation aneurysms. J Neurointerv Surg 2012;4:16-21 CrossRef Medline

20. Ko JK, Han IH, Cho WH, et al. Crossing Y-stent technique with dual open-cell stents for coiling of wide-necked bifurcation aneurysms. Clin Neurol Neurosurg 2015;132:54-60 CrossRef Medline

21. Zhao B, Yin R, Lanzino G, et al. Endovascular coiling of wide-neck and wide-neck bifurcation aneurysms: a systematic review and meta-analysis. AJNR Am J Neuroradiol 2016;37:1700-05 CrossRef Medline

22. Aguilar-Salinas P, Brasiliense LBC, Walter CM, et al. Current status of the PulseRider in the treatment of bifurcation aneurysms: a systematic review. World Neurosurg 2018;115:288-94 CrossRef Medline

23. Lee K, Park H, Park I, et al. Y-configuration stent-assisted coil embolization for wide-necked intracranial bifurcation aneurysms. J Cerebrovasc Endovasc Neurosurg 2016;18:355-62 CrossRef Medline

24. Samaniego EA, Mendez AA, Nguyen TN, et al. LVIS Jr device for Y-stent-assisted coil embolization of wide-neck intracranial aneurysms: a multicenter experience. Interv Neurol 2018;7:271-83 CrossRef Medline

25. Brassel F, Melber K, Schlunz-Hendann M, et al. Kissing-Y stenting for endovascular treatment of complex wide necked bifurcation aneurysms using Acandis Acclino stents: results and literature review. J Neurointerv Surg 2016;8:386-95 CrossRef Medline

26. Castaño C, Terceno M, Remollo S, et al. Endovascular treatment of wide-neck intracranial bifurcation aneurysms with ' $\mathrm{Y}$ '-configuration, double Neuroform stents-assisted coiling technique: experience in a single center. Interv Neuroradiol 2017;23:362-70 CrossRef Medline

27. Spiotta AM, Gupta R, Fiorella D, et al. Mid-term results of endovascular coiling of wide-necked aneurysms using double stents in a Y configuration. Neurosurgery 2011;69:421-29

28. Santillan A, Boddu S, Schwarz J, et al. LVIS Jr. stent for treatment of intracranial aneurysms with parent vessel diameter of $2.5 \mathrm{~mm}$ or less. Interv Neuroradiol 2018;24:246-53 CrossRef Medline

29. Akgul E, Balli T, Aksungur EH. Hybrid, Y-configured, dual stentassisted coil embolization in the treatment of wide-necked bifurcation aneurysms. Interv Neuroradiol 2015;21:29-39 CrossRef Medline

30. Takano N, Suzuki M, Irie R, et al. Usefulness of non-contrastenhanced MR angiography using a silent scan for follow-up after Y-configuration stent-assisted coil embolization for basilar tip aneurysms. AJNR Am J Neuroradiol 2017;38:577-81 CrossRef Medline

31. Thorell WE, Chow MM, Woo HH, et al. Y-configured dual intracranial stent-assisted coil embolization for the treatment of widenecked basilar tip aneurysms. Neurosurgery 2005;56:1035-40; discussion 1035-40 Medline

32. Zhao KJ, Yang PF, Huang QH, et al. Y-configuration stent placement (crossing and kissing) for endovascular treatment of wideneck cerebral aneurysms located at $\mathbf{4}$ different bifurcation sites. AJNR Am J Neuroradiol 2012;33:1310-16 CrossRef Medline

33. Lee WJ, Cho CS. Y-stenting endovascular treatment for ruptured intracranial aneurysms: a single-institution experience in Korea. $J$ Korean Neurosurg Soc 2012;52:187-92 CrossRef Medline

34. Chalouhi N, Jabbour P, Gonzalez LF, et al. Safety and efficacy of endovascular treatment of basilar tip aneurysms by coiling with and without stent assistance: a review of 235 cases. Neurosurgery 2012;71:785-94 CrossRef Medline

35. Johnson AK, Heiferman DM, Lopes DK. Stent-assisted embolization of 100 middle cerebral artery aneurysms. J Neurosurg 2013;118: 950-55 CrossRef Medline

36. Möhlenbruch M, Herweh C, Behrens L, et al. The LVIS Jr. microstent to assist coil embolization of wide-neck intracranial aneurysms: clinical study to assess safety and efficacy. Neuroradiology 2014;56: 389-95 CrossRef Medline

37. Heller RS, Rahal JP, Malek AM. Y-Stent embolization technique for intracranial bifurcation aneurysms. J Clin Neurosci 2014;21: 1368-72 CrossRef Medline

38. Johnson AK, Munich SA, Tan LA, et al. Complication analysis in nitinol stent-assisted embolization of 486 intracranial aneurysms. J Neurosurg 2015;123:453-59 CrossRef Medline

39. Melber K, Meila D, Draheim $P$, et al. Vascular angular remodeling by kissing-Y stenting in wide necked intracranial bifurcation aneurysms. J Neurointerv Surg 2017;9:1233-37 CrossRef

40. Bang JS, Kim $\mathrm{CH}$, Kwon BJ, et al. The difficulties and risks of $\mathrm{Y}$ stent-assisted coiling: a comparison of first and second stenting procedures. World Neurosurg 2016;88:146-53 CrossRef Medline

41. Cheung NK, Chiu AH, Cheung A, et al. Long term follow-up of bifurcation aneurysms treated with braided stent assisted coiling and complex T- and Y-stent constructs. J Neurointerv Surg 2018;10: 560-65 CrossRef Medline 